\title{
A comparison of the IED- related eye injury rate in ANSF and ISAF forces at the UK R3 Hospital, Camp Bastion, 2013
}

Sir, we would like to draw attention to an observed differential rate of eye injury between International Security Assistance Force (ISAF) and Afghan National Security Force (ANSF) troops in Afghanistan. Until recently, most conflicts had seen an increased rate of fragment-related penetrating eye injury secondary to the increased use of improvised explosive devices (IEDs). ${ }^{1}{ }^{2}$ Even within armoured vehicles, their blast spalls paint and significantly energises dust and small objects. In published military series, $20 \%$ of these injuries have been bilateral and overall have had a worse prognosis than civilian injuries. ${ }^{3}{ }^{4}$ Issued Combat Eye Protection (CEP) which offers significant eye cover has now been developed for ISAF personnel. This CEP wear (goggles or frames) is mandatory for all ISAF troops. Eye protection is, 
Table 1 A statistical comparison of the differential rates of eye injury between ANSF and ISAF troops.

\begin{tabular}{|c|c|c|c|}
\hline Total number $=94$ & ANSF & ISAF & Significance ( $p$ value) \\
\hline Number in each group (n) & 53 & 41 & - \\
\hline Mounted & $19^{*}$ & 34 & 0.0001 \\
\hline Eye protection & 0 & $40 \dagger$ & 0.0001 \\
\hline Eye injury & 24 & 3 & 0.0001 \\
\hline Bilateral injury & 11 & 0 & 0.0020 \\
\hline Corneal abrasion & 13 & 1 & 0.0028 \\
\hline Globe penetration & 9 & 1 & 0.0390 \\
\hline Eyelid laceration & 8 & 0 & 0.0088 \\
\hline Retained FB & 0 & 1 & 0.4362 \\
\hline Facial fracture & $9(17 \%)$ & $2(4.8 \%)$ & 0.1056 \\
\hline Previous injury & 2 & $1 \dagger$ & 1.000 \\
\hline
\end{tabular}

however, not routinely provided to or used by the ANSF. To investigate this, we performed a service evaluation of combat eye injuries after registration with the Deployed Medical Director (acting as the Caldicott Guardian) and the Bastion Role 3 Clinical Governance Officer.

The records of all ISAF and ANSF personnel presenting to our emergency department between 1 December 2012 and 28 February 2013 following IED incidents were examined. All data were collated, stored securely, confirmed with the Joint Theatre Trauma Register, appropriately anonymised and analysed using Fisher's Exact Test on Graphpad (Table 1).

Corresponding civilian reports document a high bomb or IED-related ocular injury rate particularly in commuter train incidents. In one civilian series, 16 of 28 bomb-injured patients $(57.1 \%)$ had ocular injuries. Injuries were unilateral in 10 patients and bilateral in six, yielding a total of 22 injured eyes. The common injuries were periorbital haemorrhages (nine eyes, 40\%), first or second degree burns to the upper or lower lids (seven eyes, 31.8\%) and corneal injuries (eight eyes, 36.3\%). Open globe injuries were seen in two eyes of two patients $(9 \%)$. One patient $(4.5 \%)$ had a traumatic optic neuropathy. Eye protection usage was not documented but was unlikely to have been worn. Interestingly, most of their serious injuries were missed or not treated at an initial assessment. ${ }^{56}$

Militarily, a US study observed 160 patients (198 eyes) with ocular injuries in Operation Desert Storm (1991), where $78 \%$ of all serious injuries were caused by blast fragmentation from munitions and over a third of the 98 globe lacerations were $10 \mathrm{~mm}$ or less in size. Overall, 33/35 enucleations performed during Operation Desert Storm were for munition fragment injury. ${ }^{1}$ By 2006, the US experience at Walter Reed had expanded to 523 cases in 387 soldiers over a 3 -year period; ${ }^{2}$ globe trauma was present in 432 eyes. These included 234 closed-globe injuries, 198 open-globe, 86 intra-ocular foreign bodies, 61 perforating injuries, 32 penetrating injuries and 19 ocular ruptures. At 6 months, 32\% of injured eyes had best corrected visual acuity of no light perception but encouragingly $42 \%$ of eyes had achieved 20/40 (6/12) vision by this point. CEP was not mandated by the US or UK military in Iraq or in the early stages of the campaign in Afghanistan. The longterm effects of primary IED blast on the closed globe, particularly the macula and optic nerve, are only now more fully understood. $^{7}$

On completion of our evaluation, we undertook informal discussions with the many ANSF troops in Camp Bastion and Camp Shorabak, and informed the Regional Command (South West) of our results. These ANSF discussions showed that they had no religious or cultural barrier to the use of eye protection. Urgent operational procurement of eye protection from the authorised Protective Eyewear List (APEL), which is a list of protective eyewear tested and approved by the US military for use by its soldiers, ${ }^{8}$ for all ANSF personnel is recommended. One further potential advantage is anecdotal reports of improved observation of IED ground sign with the issued yellow lens. Wearing of eye protection should be therefore encouraged as early as possible in military training as its use then becomes second nature. All APEL eyewear is suitable for prescription lens insertion. The significant six-fold comparative rate of devastating eye injuries currently seen in ANSF forces is likely to be preventable by the routine use of commonly available eye protection.

\section{Paul Parker, ${ }^{1}$ S Mossadegh, ${ }^{1}$ C McCrory ${ }^{2}$}

${ }^{1}$ ADMST, Queen Elizabeth Hospital, Birmingham, UK ${ }^{2}$ Hydebank, 204 Field Hospital, Belfast, Northern Ireland, UK

Correspondence to Col Paul Parker, ADMST, Queen Elizabeth Hospital, Birmingham, UK; parker_paul@hotmail.com

Contributors $\mathrm{CMCC}$ undertook the audit. SM performed the statistical analysis and table creation. PP wrote the paper and acts as guarantor.

\section{Competing interests None.}

Provenance and peer review Not commissioned; externally peer reviewed.

To cite Parker P, Mossadegh S, McCrory C. J R Army Med Corps 2014:160:73-74.

Received 5 August 2013

Revised 17 November 2013

Accepted 24 November 2013

Published Online First 19 December 2013

J R Army Med Corps 2014;160:73-74.

doi:10.1136/jramc-2013-000164

\section{REFERENCES}

1 Mader TH, Aragones JV, Chandler AC, et al. Ocular and ocular adnexal injuries treated by United States Military Ophthalmologists during Operation Desert Shield and Desert Storm. Ophthalmology 1993;100:1462-7.

2 Weichel ED, Colyer MH, Ludlow SE, et al. Combat ocular trauma visual outcomes during operations iraqi and enduring freedom. Ophthalmology 2008; 115:2235-45

3 Mansour AM, Zein WM, Sibai TA, et al. Comparison of domestic and war ocular injuries during the Lebanese Civil War. Ophthalmologica 2009;223:36-40.

4 Scott R. The injured eye. Philos Trans $R$ Soc Lond $B$ Biol Sci 2011;366:251-60.

5 Mehta S, Agarwal V, Jiandani P. Ocular injuries in survivors of improvised explosive devices (IED) in commuter trains. BMC Emerg Med 2007;7:16.

6 Alam M, Iqbal M, Khan A, et al. Ocular injuries in blast victims. J Pak Med Assoc 2012;62:138-42.

7 Phillips BN, Chun DW, Colyer M. Closed globe macular injuries after blasts in combat. Retina 2013;33:371-9.

8 http://www.health.mil/Libraries/101101 TCCC Course_Materials/0504-PEO-Soldier-AuthorizedProtective-Eyewear-List-poster-110620.pdf (accessed 10/11/13). 